\title{
C-reactive protein levels in stable COPD patients: a case-control study
}

\author{
This article was published in the following Dove Press journal: \\ International Journal of COPD \\ 31 August 2015 \\ Number of times this article has been viewed
}

\author{
Denise Rossato Silva ${ }^{1,2}$ \\ Marcelo Basso Gazzana ${ }^{1,2}$ \\ Marli Maria Knorst ${ }^{1,2}$ \\ 'Department of Internal Medicine, \\ Universidade Federal do Rio Grande \\ do Sul, ${ }^{2}$ Department of Pulmonary \\ Medicine, Hospital de Clínicas de \\ Porto Alegre, Porto Alegre, Brazil
}

\begin{abstract}
Background: Previous studies have documented that C-reactive protein (CRP) levels are increased in stable COPD patients. However, most studies have also shown that higher CRP levels are observed in patients with comorbidities like diabetes mellitus and cardiovascular disease. We aimed to investigate if CRP levels are increased in stable COPD patients, and if there is an association between CRP levels and pulmonary function tests and clinical characteristics.
\end{abstract}

Methods: We conducted a case-control study in a tertiary care, university-affiliated hospital. COPD patients and controls were matched for sex and age in a 2:1 matching ratio. We included only those patients who had quit smoking. CRP levels were determined and pulmonary function tests were performed in both the groups.

Results: A total of 60 COPD patients and 30 controls were included in the analysis. The study subjects had a mean age of $64.8 \pm 8.5$ years in COPD group and 64.3 \pm 9.2 years in control group $(P=0.214)$. The median of CRP levels was $3.17 \mathrm{mg} / \mathrm{L}$ (interquartile range [IQR]: $1.73-5.99 \mathrm{mg} / \mathrm{L}$ ) in COPD group and $2.13 \mathrm{mg} / \mathrm{L}$ (IQR: $1.18-7.69 \mathrm{mg} / \mathrm{L})$ in control group $(P=0.370)$. There were $34(56.7 \%)$ patients in COPD group and $14(46.7 \%)$ patients in control group with CRP levels greater than $3 \mathrm{mg} / \mathrm{dL}(P=0.382)$. Using bivariate correlations, we found significant positive correlations in COPD patients between body mass index (BMI) and CRP ( $r=0.3, P=0.045)$, and between CRP and forced vital capacity (FVC, $\%$ of predicted) ( $r=-0.3 ; P=0.023)$. In a multivariate model, female sex and FVC (\% of predicted) were associated with a CRP value greater than $3 \mathrm{mg} / \mathrm{dL}$ in the COPD group.

Conclusion: The levels of CRP in the stable COPD patients were not significantly different when compared to those in the control subjects. Female sex and FVC (\% predicted) were associated with CRP levels greater than $3 \mathrm{mg} / \mathrm{dL}$ in the COPD group.

Keywords: case-control study, chronic obstructive pulmonary disease, C-reactive protein, comorbidity

\section{Introduction}

Chronic obstructive pulmonary disease (COPD) is a major cause of chronic morbidity and mortality throughout the world, accounting for more than 3 million deaths annually. ${ }^{1}$ Systemic inflammation and oxidative stress are the most important features of COPD. There is an increasing interest in determining the role of biomarkers of systemic inflammation in COPD patients, as these may have possible uses in evaluating exacerbations, monitoring disease progression, and measuring the effects of treatments. ${ }^{2-4}$

C-reactive protein (CRP) is a potential biomarker of systemic inflammation that is synthesized predominantly by the hepatocytes in response to tissue damage or inflammation. ${ }^{5}$ Several previous studies have documented that CRP levels are increased in stable COPD patients. ${ }^{3,6-12}$ However, in most studies, patients with comorbidities like diabetes mellitus and cardiovascular disease, known to be associated with higher CRP levels, were not excluded..$^{3,9,10}$ In addition, in stable COPD patients, CRP was
Correspondence: Denise Rossato Silva Department of Pulmonary Medicine, Hospital de Clínicas de Porto Alegre, 2350 Ramiro Barcelos Street, Bairro Santa Cecília, Porto Alegre-RS, Brazil Tel +55 5l 3359824 I Fax +55 5I 3359800 I Email denise.rossato@terra.com.br 
shown to be negatively correlated with forced expiratory volume in 1 second $\left(\mathrm{FEV}_{1}\right)^{8}$ and grade of dyspnea, but was not correlated with age. ${ }^{13}$ On the other hand, another study demonstrated that CRP had a weak correlation with COPD severity in elderly stable patients. ${ }^{14}$

Given the conflicting results of prior studies, we aimed to investigate if CRP levels are increased in stable COPD patients, and if there is an association between CRP levels and pulmonary function tests and clinical characteristics. ${ }^{3,6-12}$

\section{Methods}

We conducted a prospective case-control study in a general, tertiary care, university-affiliated hospital. COPD patients and controls were matched for sex and age in a 2:1 matching ratio. $\mathrm{COPD}$ was confirmed in patients with a $\mathrm{FEV}_{1} / \mathrm{FVC}$ ratio of less than 0.7 , measured 20 minutes after the administration of salbutamol. COPD severity was classified according to Global Initiative for Chronic Obstructive Lung Disease (GOLD) criteria. ${ }^{15}$ Patients were classified into low-risk groups (A and $\mathrm{B})$ and high-risk groups (C and D) according to the GOLD 2011 classification..$^{15}$ The body mass index, measure of airflow obstruction, dyspnea score and exercise capacity (BODE) index was calculated as described. ${ }^{16}$ Outpatients with COPD were sequentially enrolled. Patients with COPD, referred from primary care, had regular consultations in an outpatient clinic specific for COPD patients, localized inside the hospital. The control group consisted of volunteers recruited from the same hospital, who visited other outpatients' clinics and had normal spirometry. Most of these volunteers had regular appointments for checkup and did not have any comorbidity. We only included never or former smokers with an abstinence time of more than 6 months. COPD patients with an episode of exacerbation in the last 4 weeks were excluded. We also excluded patients and controls diagnosed with asthma or cancer in the last 5 years; current or former smokers with an abstinence time of less than 6 months; suspected diagnosis of acute inflammatory or infectious disease, surgery, or trauma in the last 30 days; diabetes; heart failure; chronic renal failure; pregnancy; stroke; and ischemic heart disease. The Ethics Committee from Hospital de Clínicas de Porto Alegre approved the study, and all subjects gave written informed consent to participate in the study.

The participants were interviewed and the following data were collected through a standardized questionnaire: demographic data, smoking habits, presence of comorbidities, and inhaled corticosteroid (ICS) and oral corticosteroid use. Pulmonary function tests, including spirometry, lung volumes, and diffusing capacity of the lung for carbon monoxide
$\left[\mathrm{D}_{\mathrm{LCO}}\right]$, were performed using a computerized spirometer and a plethysmograph (Jäeger, Würzburg, Germany) according to the American Thoracic Society/European Respiratory Society guidelines ${ }^{17-19}$ and previously published reference values. ${ }^{20-22}$ A spirometry with bronchodilator was performed in the control subjects. We described only post-bronchodilator values. Blood sample was collected from all the participants and CRP levels were measured using a high sensitivity assay (Beckman Coulter, Inc., Miami, FL, USA), with a lower detection limit of $0.15 \mathrm{mg} / \mathrm{L}$. For some statistical analysis, levels of CRP were categorized using the cut-point $3 \mathrm{mg} / \mathrm{L}$, a cut-point previously used by others. ${ }^{23-25}$ Pulmonary function tests were performed in the same week that the blood measurements were taken.

Data analysis was performed using SPSS 18.0 (SPSS Inc., Chicago, IL, USA). Data were presented as number of cases, mean \pm standard deviation (SD), or median with interquartile range. Categorical comparisons were carried out by chi-square test using Yates's correction if indicated or by Fisher's exact test. Continuous variables were compared using the student's $t$-test or Wilcoxon signed-rank test. Pearson's (or Spearman's when indicated) correlations were performed to evaluate for potential relationships between CRP levels and age, BMI, pulmonary function tests, and BODE index. Multivariate logistic regression analysis was performed using factors associated with CRP levels greater than $3 \mathrm{mg} / \mathrm{dL}$ in univariate analysis $(P<=0.20)$, controlled by sex and age. Hierarchical logistic regression models with predictors added one at a time were also examined to evaluate the possible collinearity among the predictors. The goodness-of-fit of the multiple logistic regression models was assessed using the Hosmer-Lemeshow test. Odds ratios (ORs) and nominal 95\% confidence intervals (CIs) were presented. A two-sided $P$-value $<0.05$ was considered significant for all the analyses.

On the basis of data presented by de Torres et al, ${ }^{7}$ we estimated a sample size of 27 patients, under the assumptions of a type I error (two-sided) of 5\% and a power of $80 \%$, on comparison of CRP values between two groups (COPD vs control). ${ }^{26}$ In addition, to find a correlation (at least $r=0.60$ ) between CRP and other variables, with a power of $80 \%$ and significance at 5\%, 19 patients would be required. ${ }^{26}$ Once these are small sample sizes, we decided to increase the number of cases and use a 1:2 control-to-case ratio. Wacholder et $\mathrm{al}^{27}$ suggested that the best way to increase precision in a case-control study is to increase the number of cases by widening the base geographically or temporally rather than by increasing the number of controls, because the marginal increase in precision resulting from an additional case is greater than that from an additional control. 


\section{Results}

A total of 60 COPD patients and 30 controls met the inclusion criteria and were included in the analysis, after having given signed, informed consent. The characteristics of the study population are shown in Table 1.

The study subjects had a mean age of $64.8 \pm 8.5$ years in the COPD group and 64.3 \pm 9.2 years in the control group $(P=0.214)$. Patients with COPD had a lower body mass index (BMI) compared with control subjects $\left(25.3 \pm 4.5 \mathrm{~kg} / \mathrm{m}^{2}\right.$ vs $\left.28.1 \pm 4.3 \mathrm{~kg} / \mathrm{m}^{2}, P=0.006\right)$. There were 58 (96.7\%) former smokers and two (3.3\%) never smokers in the COPD group. In the control group, there were nine $(30.0 \%)$ former smokers and $21(70.0 \%)$ never smokers. The number of cigarettes smoked was higher in the COPD group (median $=46.5$ packyears) than in the control group (median $=30.0$ pack-years), but this difference was not statistically significant $(P=0.193)$. There were $20(33.3 \%)$ patients with comorbidities in the COPD group: 17 (28.3\%) with systemic arterial hypertension, nine (15.0\%) with dyslipidemia, and six (10.0\%) with osteoporosis. In control group, five (16.7\%) participants had comorbidities: two had dyslipidemia, one had systemic arterial hypertension, one had hypothyroidism, and one had restless legs syndrome. All the subjects (both cases and controls) with dyslipidemia were using synvastatin.

As expected, patients diagnosed with COPD had $\mathrm{FEV}_{1}$ (\% of predicted) and FVC (\% of predicted) values lower than the subjects in control group $(P<0.0001)$. According to the GOLD criteria, there were two (3.3\%), $20(33.3 \%)$, $21(35.0 \%)$, and 17 (28.3\%) patients with stages I, II, III, and IV disease, respectively. According to the GOLD 2011 classification, there were ten (16.7\%), six (10.0\%), 16 (26.7\%), and $28(46.7 \%)$ patients in groups A, B, C, and D, respectively. The median BODE index was 3.0 (1.5-5.0).

The median of CRP values was $3.2 \mathrm{mg} / \mathrm{L}$ (IQR: 1.7$5.9 \mathrm{mg} / \mathrm{L}$ ) in COPD group and $2.13 \mathrm{mg} / \mathrm{L}$ (IQR: $1.18-7.69$ $\mathrm{mg} / \mathrm{L})$ in control group. This difference was not statistically significant $(P=0.370)$. There were $34(56.7 \%)$ patients in COPD group and $14(46.7 \%)$ patients in control group with CRP levels greater than $3 \mathrm{mg} / \mathrm{dL}(P=0.382)$. Table 2 shows the characteristics of patients and controls with normal and abnormal CRP levels. Normal CRP levels were less frequent in females than in males (five [19.2\%] vs 21 [80.8\%], $P=0.014)$. In the control group, the number of cigarettes smoked was higher in participants with abnormal

Table I Characteristics of patients with COPD and control subjects

\begin{tabular}{|c|c|c|c|}
\hline Parameters & $\begin{array}{l}\text { COPD group } \\
(n=60)\end{array}$ & $\begin{array}{l}\text { Control group } \\
(n=30)\end{array}$ & $P$-value \\
\hline Mean age (years) & $64.8 \pm 8.5$ & $64.3 \pm 9.2$ & 0.214 \\
\hline Male (\%) & $38(63.3)$ & $20(66.7)$ & 0.755 \\
\hline Smoking pack-years & $46.5(20.6-65.5)$ & $30.0(7.5-45.5)$ & 0.193 \\
\hline Body mass index $\left(\mathrm{kg} / \mathrm{m}^{2}\right)$ & $25.3 \pm 4.5$ & $28.1 \pm 4.3$ & 0.006 \\
\hline Inhaled corticosteroid users & $40(66.7)$ & - & - \\
\hline Oral corticosteroid users & $\mathrm{I}(\mathrm{I} .7)$ & - & - \\
\hline C-reactive protein (mg/L) & $3.2(1.7-5.9)$ & $2.1(1.2-7.7)$ & 0.620 \\
\hline \multicolumn{4}{|l|}{ Pulmonary function tests } \\
\hline FVC (\% of predicted) & $70.1 \pm 22.8$ & $99.7 \pm 13.3$ & $<0.0001$ \\
\hline FEV (\% of predicted) & $43.5 \pm 19.2$ & $102.4 \pm 18.3$ & $<0.0001$ \\
\hline $\mathrm{FEV}_{1} / \mathrm{FVC}$ & $45.1 \pm 11.7$ & $80.9 \pm 7.9$ & $<0.0001$ \\
\hline TLC (\% of predicted) & $122.1 \pm 23.3$ & NA & - \\
\hline $\mathrm{D}_{\text {LCO }}(\%$ of predicted $)$ & $46.4 \pm 16.7$ & NA & - \\
\hline \multicolumn{4}{|c|}{ Severity of COPD (GOLD criteria) } \\
\hline Stage I & $2(3.3)$ & - & - \\
\hline Stage II & $20(33.3)$ & - & - \\
\hline Stage III & $21(35.0)$ & - & - \\
\hline Stage IV & $17(28.3)$ & - & - \\
\hline BODE index & $3.0(1.5-5.0)$ & - & - \\
\hline \multicolumn{4}{|l|}{ Exacerbations } \\
\hline$O$ or I in the last year & $42(70.0)$ & - & - \\
\hline$\geq 2$ in the last year & $18(30.0)$ & - & - \\
\hline
\end{tabular}

Note: Data are presented as mean $\pm S D, n(\%)$, or median (interquartile range).

Abbreviations: NA, not available; $\mathrm{FEV}_{1}$, forced expiratory volume in I second; FVC, forced vital capacity; TLC, total lung capacity; $\mathrm{D}_{\text {LCo }}$, carbon monoxide diffusing capacity of the lung; GOLD, Global Initiative for Chronic Obstructive Lung Disease (stage I: FEV $\geq 80 \%$ of predicted; II: $50 \% \leq \mathrm{FEV}$, <80\% of predicted; III: $30 \% \leq \mathrm{FEV}$, $<50 \%$ of predicted; IV: $\mathrm{FEV},<30 \%$ of predicted); BODE, body mass index, measure of airflow obstruction, dyspnea score and exercise capacity; SD, standard deviation. 
Table 2 Characteristics of patients and controls with normal and abnormal C-reactive protein levels

\begin{tabular}{|c|c|c|c|c|c|c|}
\hline \multirow[t]{2}{*}{ Parameters } & \multicolumn{3}{|c|}{ COPD group $(n=60)$} & \multicolumn{3}{|c|}{ Control group $(n=30)$} \\
\hline & $\begin{array}{l}\text { Abnormal CRP } \\
(n=34)\end{array}$ & $\begin{array}{l}\text { Normal CRP } \\
(n=26)\end{array}$ & $P$-value & $\begin{array}{l}\text { Abnormal CRP } \\
(n=14)\end{array}$ & $\begin{array}{l}\text { Normal CRP } \\
(n=16)\end{array}$ & $P$-value \\
\hline Mean age (years) & $64.7 \pm 9.0$ & $64.8 \pm 7.9$ & 0.988 & $64.9 \pm 8.7$ & $63.9 \pm 9.9$ & 0.776 \\
\hline Female (\%) & $17(50.0)$ & $5(19.2)$ & 0.014 & $10(71.4)$ & $10(62.5)$ & 0.709 \\
\hline Smoking pack-years & $4 \mathrm{I}(19.0-62.5)$ & $51(32.1-72.0)$ & 0.115 & $40(35.0-79.5)$ & $7.5(3.0-24.4)$ & 0.018 \\
\hline Body mass index $\left(\mathrm{kg} / \mathrm{m}^{2}\right)$ & $25.7 \pm 5.1$ & $24.7 \pm 3.5$ & 0.380 & $29.2 \pm 5.0$ & $27.1 \pm 3.5$ & 0.196 \\
\hline Inhaled corticosteroid users & $25(73.5)$ & $15(57.7)$ & 0.271 & - & - & - \\
\hline Two or more exacerbations in the past year & $10(29.4)$ & $8(30.8)$ & 0.999 & - & - & - \\
\hline FVC (\% of predicted) & $60.7 \pm 16.4$ & $70.2 \pm 20.9$ & 0.054 & $100.1 \pm 13.5$ & $99.4 \pm 13.6$ & 0.895 \\
\hline $\mathrm{FEV}_{\text {, }}(\%$ of predicted) & $36.3 \pm 14.3$ & $40.1 \pm 16.9$ & 0.351 & $100.3 \pm 18.3$ & $104.3 \pm 18.6$ & 0.562 \\
\hline $\mathrm{FEV}_{1} / \mathrm{FVC}$ & $44.8 \pm 12.1$ & $46.2 \pm 11.1$ & 0.646 & $78.5 \pm 7.1$ & $83.1 \pm 8.2$ & 0.117 \\
\hline BODE index & $3.0(1.0-5.3)$ & $3.0(2.0-5.0)$ & 0.814 & - & - & - \\
\hline \multicolumn{7}{|l|}{ Severity of COPD (GOLD criteria) } \\
\hline Stage I & $6(17.6)$ & $4(15.4)$ & 0.66 & - & - & - \\
\hline Stage II & $2(5.9)$ & $4(15.4)$ & - & - & - & - \\
\hline Stage III & $9(26.5)$ & $7(26.9)$ & - & - & - & - \\
\hline Stage IV & $17(50.0)$ & II (42.3) & - & - & - & - \\
\hline
\end{tabular}

Notes: There was only one smoker in this subgroup. Data are presented as mean $\pm \mathrm{SD}, \mathrm{n}(\%)$, or median (interquartile range).

Abbreviations: NA, not available; FEV , forced expiratory volume in I second; FVC, forced vital capacity; CRP, C-reactive protein; GOLD, Global Initiative for Chronic Obstructive Lung Disease (stage I: $\mathrm{FEV}, \geq 80 \%$ of predicted; II: $50 \% \leq \mathrm{FEV},<80 \%$ of predicted; III: $30 \% \leq \mathrm{FEV},<50 \%$ of predicted; IV: FEV,$<30 \%$ of predicted); BODE, body mass index, measure of airflow obstruction, dyspnea score and exercise capacity; SD, standard deviation.

CRP (40 [35.0-79.5] pack-years) levels than in those with normal CRP (7.5 [3.0-24.4] pack-years) levels. There were no differences in CRP levels in COPD patients according to GOLD criteria, number of exacerbations in the last year, and ICS use. Only one patient was using oral corticosteroid and he had a normal CRP value (0.42).

Logistic regression analysis, estimating the odds ratios (ORs) of risk of having a CRP value greater than $3 \mathrm{mg} / \mathrm{dL}$ (abnormal CRP), was conducted for patients and controls separately. The variables such as age, sex, smoking pack-years, FVC ( $\%$ of predicted), and $\mathrm{FEV}_{1}$ ( $\%$ of predicted) were included in the model. Only female sex (OR: 6.85, 95\% confidence interval $[\mathrm{CI}]: 1.7-27.5 ; P=0.007)$ and $\mathrm{FVC}(\%$ of predicted) (OR: 1.043, 95\% CI: $1.007-1.080 ; P=0.019)$ were observed to be associated with abnormal CRP levels. In the control group, the variables included in the analysis were age, sex, smoking pack-years, and BMI. None of the variables was found to be associated with abnormal CRP levels in the multivariate model.

Using bivariate correlations, we found significant positive correlations between BMI and CRP in COPD patients $(r=0.3$, $P=0.045$ ) (Table 3). There was no correlation between CRP and $\mathrm{BMI}$ in control group $(P=0.097)$. In COPD patients, correlation was found between $\mathrm{CRP}$ and $\mathrm{FVC}$ ( $\%$ of predicted) ( $r=-0.3 ; P=0.023)$. In both COPD and control groups, no correlation was observed between $\mathrm{FEV}_{1}$ ( $\%$ of predicted) and CRP ( $r=-0.094$ and $P=0.473$ for COPD group; $r=-0.20$ and $P=0.323$ for control group).

Table 3 Bivariate correlations with C-reactive protein in COPD patients and controls

\begin{tabular}{|c|c|c|c|c|}
\hline \multirow[t]{2}{*}{ Parameters } & \multicolumn{2}{|c|}{ COPD group } & \multicolumn{2}{|c|}{ Control group } \\
\hline & $r$ & $P$-value & $r$ & $P$-value \\
\hline Mean age (years) & -0.008 & 0.952 & 0.1 & 0.495 \\
\hline Body mass index $\left(\mathrm{kg} / \mathrm{m}^{2}\right)$ & 0.3 & $0.045^{*}$ & 0.3 & 0.097 \\
\hline \multicolumn{5}{|l|}{ Pulmonary function tests } \\
\hline FVC (\% of predicted) & -0.3 & $0.023^{*}$ & -0.08 & 0.682 \\
\hline $\mathrm{FEV}_{1}$ (\% of predicted) & -0.094 & 0.473 & -0.2 & 0.323 \\
\hline $\mathrm{FEV}_{1} / \mathrm{FVC}$ & 0.2 & 0.153 & -0.2 & 0.343 \\
\hline TLC (\% of predicted) & 0.003 & 0.984 & NA & - \\
\hline$D_{\text {LCO }}(\%$ of predicted $)$ & 0.043 & 0.764 & NA & - \\
\hline BODE index & 0.050 & 0.713 & NA & - \\
\hline
\end{tabular}

\footnotetext{
Note: $* p<0.05$.
}

Abbreviations: NA, not available; COPD, chronic obstructive pulmonary disease; FEV , forced expiratory volume in I second; FVC, forced vital capacity; TLC, total lung capacity; $\mathrm{D}_{\mathrm{LCO}}$, carbon monoxide diffusing capacity of the lung; BODE, body mass index, measure of airflow obstruction, dyspnea score and exercise capacity. 


\section{Discussion}

In this case-control study, we aimed to evaluate if CRP levels were different in clinically stable COPD and control subjects, and whether there was an association between pulmonary function tests and CRP. We demonstrated that CRP levels were not statistically different between COPD patients and controls. In a multivariate model, female sex and FVC (\% predicted) were associated with a CRP value greater than $3 \mathrm{mg} / \mathrm{dL}$ in COPD group. Also, using bivariate correlations, we found significant positive correlations between BMI and $\mathrm{CRP}$, and between FVC (\% of predicted) and CRP in the COPD patients.

Several studies ${ }^{2,3,6,7,9-11,28}$ have demonstrated that concentration of CRP is increased in clinically stable COPD patients as compared to healthy controls. However, CRP is an acute phase protein and is elevated during many conditions. It is well known that patients with COPD have a higher risk of developing cardiovascular diseases and cardiovascular-related death. ${ }^{15,29}$ Systemic inflammation has a role in endothelial dysfunction and is associated with the risk of cardiovascular diseases and mortality. ${ }^{30}$ In addition, higher CRP levels were found in patients with diabetes mellitus and cardiovascular disease. ${ }^{31}$ Data on these comorbidities were not collected in some studies that showed increased levels of CRP in COPD patients. ${ }^{3,9,10}$ Therefore, the possibility of residual confounding cannot be completely excluded. We did not find difference in CRP levels between cases and controls, but we excluded patients with the most common comorbidities related to chronic inflammation, such as cardiovascular disease, diabetes mellitus, cancer, and current smoking.

In the present study, there was no difference in CRP concentrations between groups of COPD patients when subdivided according to the severity of the disease. It has been previously described that patients with COPD had serum CRP levels higher than those in healthy controls, and that patients with severe COPD had serum CRP levels higher than those with moderate COPD. ${ }^{28}$ Serum CRP concentrations were significantly higher in COPD patients (stages III and IV) compared to patients in stage I or II. ${ }^{8}$ The small sample size in each subgroup of severity precludes a definitive conclusion in our study.

$\mathrm{CRP}$ and $\mathrm{FVC}$ (\% of predicted) values were weekly correlated in our study, and FVC (\% of predicted) was associated with abnormal CRP levels in a multivariate analysis. The negative associations between CRP and FVC have been previously demonstrated in several studies. ${ }^{24,30,32}$ It was found that as lung function improved, systemic inflammation declined, and as the inflammation increased, the lung function deteriorated. The possible mechanism involved in this association is that chronic inflammation enhances telomere shortening, which in turn leads to senescence of lung alveolar and endothelial cells. ${ }^{33,34}$ In addition, systemic inflammation induces endothelial dysfunction, resulting in pulmonary vascular infiltration and lung tissue damage. ${ }^{35}$

We found a positive, although weak, correlation between BMI and CRP levels in COPD patients. Elevated levels of CRP have been reported in overweight adults. ${ }^{36,37}$ Several studies have demonstrated a positive relationship between CRP levels and BMI in COPD patients. ${ }^{6,11,38,39}$ Obese COPD patients (BMI $\geq 30 \mathrm{~kg} / \mathrm{m}^{2}$ ) were 3.3 times more likely to have highly elevated CRP levels compared to those of normal weight (BMI 21-24.9 $\mathrm{kg} / \mathrm{m}^{2}$ ). ${ }^{39}$ However, according to the logistic regression analysis conducted in this study, BMI was not associated with abnormal CRP levels. Maybe in another study it will be more accurate to match the groups also on BMI.

In our study, normal CRP levels were less frequent in woman than in men in the COPD group. One study showed that female sex was associated with increased CRP levels. ${ }^{8}$ A sex-related effect on CRP levels was also found in the analysis of NHANES data, with higher levels in females. ${ }^{40} \mathrm{~A}$ heightened inflammatory response due to cigarette smoking in woman may explain this finding. We excluded current smokers, but the inflammatory response in the airways in COPD patients may persist even after smoking cessation. ${ }^{41}$ This could explain the effect of lifetime smoking (pack-years) on CRP levels in our control group. Smoking pack-years were significant predictors of CRP levels in a previous investigation. ${ }^{8}$ Several studies have shown that current smokers have higher CRP levels than nonsmokers, ${ }^{37,42,43}$ and that there is a positive association with the number of pack-years smoked. ${ }^{44}$

We could not find an association between ICS use and CRP levels, although a previous study showed that CRP levels were lower in COPD patients treated with ICS than in those who were not treated. ${ }^{11}$ The number of exacerbations was also not associated with CRP levels in our study, which could be related to the small number of patients with two or more exacerbations in the past year. Nevertheless, no difference was shown in CRP levels between frequent and infrequent exacerbators in another report. ${ }^{45}$

Our study includes some limitations. First, the investigation was done in a single center, and was conducted with a small sample size. In addition, we excluded active smokers from cases and from controls, because it was previously demonstrated that CRP levels were significantly higher for current smokers compared with former smokers and never smokers. ${ }^{46}$ However, exclusion of active smokers 
affects the generalization of our results, because in clinical practice, there are many patients with COPD who still smoke. Furthermore, we did not measure other systemic biomarkers that may be of interest in COPD and more sensitive than CRP. Finally, there were only two patients with COPD stage I in our study, so that our results might not be valid to this subgroup of patients. On the other hand, the strength of the present study is that we excluded patients with the most common comorbidities related to chronic inflammation, which can influence CRP levels.

\section{Conclusion}

In conclusion, we found that levels of CRP in stable COPD were not different as compared to control subjects. In addition, in a multivariate model, female sex and FVC (\% predicted) were associated with a CRP level greater than $3 \mathrm{mg} / \mathrm{dL}$ in the COPD group. These results if confirmed in a larger study, which also excludes patients with comorbidities related to chronic inflammation, could contribute to a better understanding of CRP concentrations in COPD patients.

\section{Acknowledgment}

Funding for this study was provided by FIPE-HCPA (Fundo de Incentivo à Pesquisa - Hospital de Clínicas de Porto Alegre). The FIPE-HCPA had no further role in study design; in the collection, analysis, and interpretation of data; in the writing of the report; or in the decision to submit the paper for publication.

\section{Author contributions}

DRS carried out literature search, data collection, study design, analysis of data, and manuscript preparation. MBG contributed to literature search, study design, and review of the paper. MMK contributed to literature search, study design, analysis of data, and review of the paper. All authors contributed toward data analysis, drafting and critically revising the paper and agree to be accountable for all aspects of the work.

\section{Disclosure}

The authors report no conflicts of interest in this work.

\section{References}

1. Barnes PJ. Chronic obstructive pulmonary disease. $N$ Engl J Med. 2000;343:269-280.

2. Gan WQ, Man SF, Senthilselvan A, Sin DD. Association between chronic obstructive pulmonary disease and systemic inflammation: a systematic review and a meta-analysis. Thorax. 2004;59:574-580.

3. Schols AM, Buurman WA, Staal van den Brekel AJ, Dentener MA, Wouters EF. Evidence for a relation between metabolic derangements and increased levels of inflammatory mediators in a subgroup of patients with chronic obstructive pulmonary disease. Thorax. 1996;51:819-824.
4. Sin DD, Man SF. Why are patients with chronic obstructive pulmonary disease at increased risk of cardiovascular diseases? The potential role of systemic inflammation in chronic obstructive pulmonary disease. Circulation. 2003;107:1514-1519.

5. Pepys MB, Hirschfield GM. C-reactive protein: a critical update. J Clin Invest. 2003;111:1805-1812.

6. Broekhuizen R, Wouters EF, Creutzberg EC, Schols AM. Raised CRP levels mark metabolic and functional impairment in advanced COPD. Thorax. 2006;61:17-22.

7. de Torres JP, Cordoba-Lanus E, Lopez-Aguilar C, et al. C-reactive protein levels and clinically important predictive outcomes in stable COPD patients. Eur Respir J. 2006;27:902-907.

8. El-Deek SE, Makhlouf HA, Saleem TH, Mandour MA, Mohamed NA. Surfactant protein D, soluble intercellular adhesion molecule-1 and high-sensitivity C-reactive protein as biomarkers of chronic obstructive pulmonary disease. Med Princ Pract. 2013;22:469-474.

9. Firouzjahi A, Monadi M, Karimpoor F, et al. Serum C-reactive protein level and distribution in chronic obstructive pulmonary disease versus healthy controls: a case-control study from Iran. Inflammation. 2013;36:1122-1128.

10. Karadag F, Kirdar S, Karul AB, Ceylan E. The value of C-reactive protein as a marker of systemic inflammation in stable chronic obstructive pulmonary disease. Eur J Intern Med. 2008;19:104-108.

11. Pinto-Plata VM, Mullerova H, Toso JF, et al. C-reactive protein in patients with COPD, control smokers and non-smokers. Thorax. 2006; 61:23-28.

12. Torres-Ramos YD, Garcia-Guillen ML, Olivares-Corichi IM, Hicks JJ. Correlation of plasma protein carbonyls and C-reactive protein with GOLD stage progression in COPD patients. Open Respir Med J. 2009; 3:61-66.

13. Shameem M, Bhargava R, Ahmad Z, Saad T, Fatima N, Malik A. Association between serum C-reactive protein levels and other important predictive markers of outcome in COPD. Acta Med Iran. 2011; 49:18-20.

14. Corsonello A, Pedone C, Battaglia S, Paglino G, Bellia V, Incalzi RA. C-reactive protein (CRP) and erythrocyte sedimentation rate (ESR) as inflammation markers in elderly patients with stable chronic obstructive pulmonary disease (COPD). Arch Gerontol Geriatr. 2011;53:190-195.

15. Vestbo J, Hurd SS, Agusti AG, et al. Global strategy for the diagnosis, management, and prevention of chronic obstructive pulmonary disease: GOLD executive summary. Am J Respir Crit Care Med. 2013; 187:347-365.

16. Celli BR, Cote CG, Marin JM, et al. The body-mass index, airflow obstruction, dyspnea, and exercise capacity index in chronic obstructive pulmonary disease. $N$ Engl J Med. 2004;350:1005-1012.

17. MacIntyre N, Crapo RO, Viegi G, et al. Standardisation of the single-breath determination of carbon monoxide uptake in the lung. Eur Respir J. 2005;26:720-735.

18. Miller MR, Hankinson J, Brusasco V, et al. Standardisation of spirometry. Eur Respir J. 2005;26:319-338.

19. Wanger J, Clausen JL, Coates A, et al. Standardisation of the measurement of lung volumes. Eur Respir J. 2005;26:511-522.

20. Crapo RO, Morris AH, Gardner RM. Reference spirometric values using techniques and equipment that meet ATS recommendations. Am Rev Respir Dis. 1981;123:659-664.

21. Crapo RO, Morris AH. Standardized single breath normal values for carbon monoxide diffusing capacity. Am Rev Respir Dis. 1981;123:185-189.

22. Crapo RO, Morris AH, Clayton PD, Nixon CR. Lung volumes in healthy nonsmoking adults. Bull Eur Physiopathol Respir. 1982;18:419-425.

23. Dahl M, Vestbo J, Lange P, Bojesen SE, Tybjaerg-Hansen A, Nordestgaard BG. C-reactive protein as a predictor of prognosis in chronic obstructive pulmonary disease. Am J Respir Crit Care Med. 2007;175:250-255.

24. Dahl M, Vestbo J, Zacho J, Lange P, Tybjaerg-Hansen A, Nordestgaard BG. C reactive protein and chronic obstructive pulmonary disease: a Mendelian randomisation approach. Thorax. 2011;66: 197-204. 
25. Zacho J, Tybjaerg-Hansen A, Jensen JS, Grande P, Sillesen H, Nordestgaard BG. Genetically elevated C-reactive protein and ischemic vascular disease. N Engl J Med. 2008;359:1897-1908.

26. Browner WS, Newman TB, Hulley SB. Estimating sample size and power: applications and examples. In: Hulley SB, Cummings SR, Browner WS, Grady DG, Newman TB, editors. Designing Clinical Research. 3rd ed. Philadelphia: Lippincott Williams \& Wilkins; 2007:65-94.

27. Wacholder S, Silverman DT, McLaughlin JK, Mandel JS. Selection of controls in case-control studies. III. Design options. Am J Epidemiol. 1992;135:1042-1050.

28. Zhang Y, Bunjhoo H, Xiong W, Xu Y, Yang D. Association between C-reactive protein concentration and chronic obstructive pulmonary disease: a systematic review and meta-analysis. J Int Med Res. 2012; 40:1629-1635.

29. Agusti A, Soriano JB. COPD as a systemic disease. COPD. 2008;5: 133-138.

30. Kaptoge S, Di AE, Lowe G, et al. C-reactive protein concentration and risk of coronary heart disease, stroke, and mortality: an individual participant meta-analysis. Lancet. 2010;375:132-140.

31. Hersh CP, Miller DT, Kwiatkowski DJ, Silverman EK. Genetic determinants of C-reactive protein in COPD. Eur Respir J. 2006;28: 1156-1162.

32. van Durme YM, Verhamme KM, Aarnoudse AJ, et al. C-reactive protein levels, haplotypes, and the risk of incident chronic obstructive pulmonary disease. Am J Respir Crit Care Med. 2009;179: 375-382.

33. MacNee W. Aging, inflammation, and emphysema. Am J Respir Crit Care Med. 2011;184:1327-1329.

34. Tuder RM, Kern JA, Miller YE. Senescence in chronic obstructive pulmonary disease. Proc Am Thorac Soc. 2012;9:62-63.

35. Clapp BR, Hingorani AD, Kharbanda RK, et al. Inflammation-induced endothelial dysfunction involves reduced nitric oxide bioavailability and increased oxidant stress. Cardiovasc Res. 2004;64:172-178.

36. Visser M, Bouter LM, McQuillan GM, Wener MH, Harris TB. Elevated C-reactive protein levels in overweight and obese adults. JAMA. 1999;282:2131-2135.
37. Danesh J, Wheeler JG, Hirschfield GM, et al. C-reactive protein and other circulating markers of inflammation in the prediction of coronary heart disease. N Engl J Med. 2004;350:1387-1397.

38. Melbye H, Halvorsen DS, Hartz I, et al. Bronchial airflow limitation, smoking, body mass index, and statin use are strongly associated with the C-reactive protein level in the elderly. The Tromso Study 2001. Respir Med. 2007;101:2541-2549.

39. Breyer MK, Spruit MA, Celis AP, Rutten EP, Janssen PP, Wouters EF. Highly elevated C-reactive protein levels in obese patients with COPD a fat chance? Clin Nutr. 2009;28:642-647.

40. Woloshin S, Schwartz LM. Distribution of C-reactive protein values in the United States. N Engl J Med. 2005;352:1611-1613.

41. Hogg JC, Chu F, Utokaparch S, et al. The nature of small-airway obstruction in chronic obstructive pulmonary disease. $N$ Engl J Med. 2004 350:2645-2653.

42. Tamakoshi K, Yatsuya H, Kondo T, et al. Long-term body weight variability is associated with elevated C-reactive protein independent of current body mass index among Japanese men. Int J Obes Relat Metab Disord. 2003;27:1059-1065.

43. Gan WQ, Man SF, Sin DD. The interactions between cigarette smoking and reduced lung function on systemic inflammation. Chest. 2005; 127:558-564.

44. Frohlich M, Sund M, Lowel H, Imhof A, Hoffmeister A, Koenig W. Independent association of various smoking characteristics with markers of systemic inflammation in men. Results from a representative sample of the general population (MONICA Augsburg Survey 1994/95). Eur Heart J. 2003;24:1365-1372.

45. Gompertz S, Bayley DL, Hill SL, Stockley RA. Relationship between airway inflammation and the frequency of exacerbations in patients with smoking related COPD. Thorax. 2001;56:36-41.

46. Tonstad S, Cowan JL. C-reactive protein as a predictor of disease in smokers and former smokers: a review. Int J Clin Pract. 2009 63:1634-1641
International Journal of COPD

\section{Publish your work in this journal}

The International Journal of COPD is an international, peer-reviewed journal of therapeutics and pharmacology focusing on concise rapid reporting of clinical studies and reviews in COPD. Special focus is given to the pathophysiological processes underlying the disease, intervention programs, patient focused education, and self management protocols.

\section{Dovepress}

This journal is indexed on PubMed Central, MedLine and CAS. The manuscript management system is completely online and includes a very quick and fair peer-review system, which is all easy to use. Visit http://www.dovepress.com/testimonials.php to read real quotes from published authors. 